\title{
Aporias of Blame and Punishment in Simone de Beauvoir's "Fil pour Fil"
}

\author{
Lior Levy (i) \\ Department of Philosophy, University of Haifa, Haifa, Israel \\ Corresponding author. levyliord@gmail.com
}

(Received 10 September 2019; revised 4 August 2020; accepted 10 August 2020; first published online 3 November 2021)

\begin{abstract}
This essay concerns Simone de Beauvoir's analysis of blame and punishment in "CEil pour œil" and the irreconcilable tensions that haunt it. I study these tensions-between the desire to blame and punish and the inability to provide moral justification for these practices-and locate their source in Beauvoir's conception of ethics in Pour une morale de l'ambiguïté. According to my reading, her ethics implies that violence violates freedom, the grounding principle of ethical life. Retaliatory and retributive judgments and the punishment they uphold, regardless of whether they are exerted by individuals or by official state powers, are forms of violence and are therefore unjustifiable. The aporias of blame and punishment in "EEil pour œil" suggest that Beauvoir's ideal of ethics necessitates an abolitionist position regarding punishment. The essay ends with a reflection on the affinity between the position constructed from Beauvoir's work and feminist abolitionist theories that seek to undermine the legal, social, and political institutions that perpetuate, rather than resolve, economic, racial, gender, sex, and class inequality.
\end{abstract}

Following the trial and execution of Robert Brasillach by the French government, Simone de Beauvoir published "Eil pour œil," where she examines the existential and moral status of blaming and punishing (Beauvoir 1946). In addition to advancing a phenomenology of vengeance, the essay examines the ethical legitimacy of legal and political judgments and the punishments they uphold, as well as instances when blame and punishment are replaced by understanding or forgiveness. ${ }^{1}$ Her meditation on and evaluation of different systems of justice and punishment are developed vis-à-vis two categories of crime: ordinary crimes, which can be understood and forgiven, and "absolute evils," which necessitate judgment and punishment.

Although Beauvoir explicitly argues for the necessity of retaliation and retribution, she portrays them as lacking justification. I define Beauvoir's conceptions of retaliation and retribution, study her ambivalence toward them, and account for it. Although I follow Beauvoir's central claim in focusing on blame and punishment as responses to absolute evil, I nonetheless draw on her discussion to consider the tendency to

(c) The Author(s), 2021. Published by Cambridge University Press on behalf of Hypatia, a Nonprofit Corporation. This is an Open Access article, distributed under the terms of the Creative Commons Attribution licence (http://creativecommons. org/licenses/by/4.0/), which permits unrestricted re-use, distribution, and reproduction in any medium, provided the original work is properly cited. 
blame and punish more generally. If there is an internal difficulty in justifying these practices in the severe cases of absolute evil, it will be equally problematic to justify them in ordinary or mundane contexts.

I identify a series of aporias in Beauvoir's account: the necessity to hold agents accountable for their crimes and the problematization of our standing to blame; the desire to punish absolute evil, and doubt regarding the adequacy of retaliation and retribution as justifications for punishment. I then trace these irreconcilable tensions to Beauvoir's ethics, specifically to her understanding of freedom as both the ground and telos of ethical life. With this position, it follows that violence violates freedom. Since punishment, whether it is carried out by individuals or by the state, is a form of violence, it cannot be justified by freedom, and it violate ethics. ${ }^{2}$ Thus, despite the fact that blame and punishment are meant to defend freedom and safeguard the sphere of the ethical against absolute evil, Beauvoir does not wholeheartedly endorse retaliation or retribution. In the final section of the essay I return to the questions of justifying blaming and punishing and suggest that although there are clear cases for assigning blameworthiness to agents, Beauvoir's position demands eschewing punishment as an expression of blame. The essay ends with an examination of the relationship between Beauvoir's ethics and feminist abolitionism, which sees punishment in toto as perpetuating injustice.

Feminist abolitionism deals with a broad spectrum of questions, from the specifically feminist concern with the justification of nonpunitive responses to sexual violence against women (Taylor 2009), to the metafeminist question of the contribution of liberal feminism to the expansion of penal power and the possibility of developing liberatory feminist practices committed to the eradication of punishment and state violence (Whalley and Hackett 2017). Relevant to our discussion is the call for penal abolition, which analyzes the racial, gendered, and classist ideologies active in the formation of historical categories of crime and rejects the tendency to think of punishment as a natural consequence of crime. In this respect, the demand to abolish punishment is a genuinely feminist goal, even when it is not framed explicitly in feminist terms, since it calls for the annihilation of gendered, racial, and economic structures that produce the penitentiary system. The appeal to create alternative institutions and practices that would render prisons obsolete is also congruent with the feminist aim of creating an egalitarian and just society.

Beauvoir's comments about pre- and postwar justice, her ambivalence about retaliation and retribution, and her ideal for an ethics imply that there are certain cases in which we need to rethink the category of crime altogether, whereas in cases of "absolute evil," we should turn to restitution and restoration, to forgiveness and pardon, as alternatives to punishment. Her ethics calls us to take heed of the risks involved in existing punitive practices, risks of perpetuating structural inequality and betraying freedom as the guiding principle of ethical life.

\section{Aporias of Punishment and Ethical Failures}

Beauvoir's ambivalence about punishment is expressed in the aporias that conclude "Eil pour œil." To punish "is to will the good" (Beauvoir 2004, 259), and yet "all punishment is a failure" (254) or at least "partially a failure" (258). Her search for a philosophical justification for retaliation and retribution intensifies this contradiction. In instances where revenge can reverse a wrong, it does not constitute judgment per se. When, by contrast, revenge is expressed in retaliatory judgments, it fails to achieve its ultimate goal of effacing the evil that was committed. Moreover, retaliation as a 
code of justice runs the risk of being tyrannical and unjust. Although retribution eludes these risks, retributive judgments issued by courts are unjustifiable, and the punishments resulting from them seem "abominable" (254). ${ }^{3}$ Hence, although Beauvoir claims that certain crimes must be the object of legal and political judgments, there is an unbridgeable gap between the recognition of an absolute evil and the legitimacy of its denunciation through punishment. ${ }^{4}$

Prima facie, the failure to provide an ultimate justification for punishment resembles the existential failures that characterize all human action. In Pour une morale de l'ambiguïté (Beauvoir 1947), Beauvoir claims that there is an "element of failure" in any human undertaking (Beauvoir 1948, 99). Action involves antinomies-irresolvable tensions between desired goals and unknown consequences of our acts, between the agent's freedom and that of other human beings affected by the agent's deeds. The root of this failure is the desire to be God-the "useless passion" to simultaneously possess a nature or essence and be free (10). The failure, which defines the human condition, is "definitive, but. . . also ambiguous" (11). It is definitive inasmuch as the synthesis between freedom and being is impossible for humans; it is ambiguous, as it is the condition for the emergence of values and, as such, provides content for an ethics, from which it can consequently be judged a failure.

Beauvoir seems to express a similar point in "Eil pour œil," when she says that the inability to justify judgment is rooted in "the ambiguity of man's condition" (Beauvoir 2004, 258). Furthermore, as we saw, she describes punishment as (at least in part) a failure, using the same language that she will use later in Pour une morale. Yet there is a cardinal difference between the two failures. The failure described in Pour une morale is both the condition for ethics and a task to be dealt with throughout life. ${ }^{5}$ Failures within the ethical are ambiguous and are "not surpassed, but assumed" (Beauvoir 1948, 13). The impossible desire to found as absolute the values we constitute has to be negotiated throughout life, in concert with action in the world. Moreover, one can become aware of the desire to be God and, at that moment, which Beauvoir identifies with conversion (to the authentic pursuit of freedom), failure turns into success. One realizes that freedom is not only the foundation of all values (and hence, of every ethics), but also the goal of action. Thus, somewhat paradoxically, conversion "prevents any possibility of failure by refusing to set up as absolutes the ends toward which my transcendence thrusts itself" (14).

Failures to justify blame and punishment are of a different kind-not ambiguous, but absolute, first and foremost because they involve a "spilling of blood" (Beauvoir 2004, 254). These failures lead to an irreversible point-the death of the culpable agent-and from that point onward, they cannot be tested or questioned through action. Moreover, punishment presented itself as a failure, disappointing even those who dreamed during the war of punishing the culprits. ${ }^{6}$ This was not only due to accidental features, like the circumstances in which punishment was inflicted, or how the culpable agent suffered it, but rather because of some essential feature of punishment. Retaliation and retribution fail to meet the condition for genuine moral action: "popular revenge expresses the passions of the moment instead of manifesting a reflective act of will, and professional judges can do nothing but obey commands. In them there is no concrete will" (258). Hence, the failure of punishment is nothing like the failure embedded in free, ethical action. The latter can unfurl "creatively" and "happily" (Beauvoir 1948 , 27), integrating its past moments into the present, while holding in view the openness of the future and "the possibility of new creations" (28). 


\section{Punishment and its Alternatives: Phenomenological and Normative Perspectives}

Sonia Kruks, reading "EEil pour œil” as a phenomenological analysis of revenge, effectively unpacks Beauvoir's assessment of the impossibility of satisfying revenge, but stresses that this does not render the desire unhealthy or blind. On the contrary, the wish for revenge remains "a meaningful demand for recognition and restitution" (Kruks 2012, 180). Although I agree that Beauvoir presents retaliation and retribution as impossible projects, I disagree with Kruks's sense of their containing a positive if unrealizable ideal. I think that Beauvoir presents them as ultimately unjustifiable, addressing them through the normative question, "is it [revenge] well founded?" (Beauvoir 2004, 247). Whereas the desire for revenge, the sentiments that feed it, can be made intelligible through a phenomenological analysis, punishment cannot be justified, either by the logic of retaliation or retribution. My analysis focuses on the normative, rather than the phenomenological question. ${ }^{7}$

Punishment lacks efficacy. It does not prevent future crimes by "making an example" (Beauvoir 2004, 247). If our aim is the consolidation of the ethical through the restoration of justice or the education of new generations toward a commitment to freedom, then we ought to "renounce punishment" (247). Indeed, the essay opens by outlining precisely such a position. Beauvoir describes how, before the war, she and others eschewed punishment altogether; later in the essay this position emerges again as a viable, ethical alternative.

Renunciation of judgment is not couched in fear of judging, which itself rests on a deterministic view of human action. ${ }^{8}$ Instead, in some instances, blame and punishment are replaced by understanding and forgiveness, in order to broaden the conception of freedom. The reference here is to both the perpetrator's freedom (who committed crimes because he is free, but whose freedom cannot be reduced to the criminal act) and the person who understands or forgives (expanding her empathy, her ability to imagine other standpoints, and suspending the tendency to assign blame or, if blame is assigned, the need to address it through punishment). Thus, the decision to understand or forgive instead of condemning and punishing broadens the sphere of an ethics of freedom-either by treating agents as free and worthy of respect, despite the wrong that they have done, in the case of forgiveness, or by insisting on the creation of a more equal society in which individuals have other venues for action than crime, in the case of understanding. Beauvoir explicitly distinguishes understanding from forgiveness, holding that understanding criminals does not necessarily result in exonerating them (257). However, when forgiveness is the desired goal, understanding the material conditions or the subjective reality that begot the crime is purposefully chosen as a means.

\section{Understanding and Forgiving}

Before the war, Beauvoir says, crimes were the outcome of an uneven, and hence unjust, distribution of social goods. Under such conditions, punishing even heinous crimes such as murder was unjust. Punishment betrays the ethical commitment to freedom as a value, one's own freedom, as well as that of others. "To will oneself moral and to will oneself free are one and the same decision," says Beauvoir (Beauvoir $1948,24)$, adding that "to will oneself free is also to will others free" (73). The subject's ability to freely choose and realize projects hinges on the existence of other free subjects, who can assist in the pursuit, development, and completion of those projects. Inequality can prevent people from freely determining and carrying out their projects. Tolerating 
or enforcing the poverty of others thwarts their freedom. The poor and the disenfranchised are busy pursuing the bare necessities of life. Theft and even murder, Beauvoir suggests, are actions taken to sustain embattled lives.

One can condemn such actions only from a position of privilege, a position that refuses to recognize the other's freedom. When society judged and punished "murderers and thieves" whom it "denounced as harmful" (Beauvoir 1946, 813), it did so because it valorized the sanctity of private property, for example, over concern for the well-being of the poor. A person who is genuinely committed to freedom "will not hesitate to sacrifice the comfort, luxury, and leisure of certain men to assure the liberation of certain others" (Beauvoir 1948, 145). If the purpose of punishment is to cast the doing and the doer outside normative limits, punishing the agent for violating the ethical principles that underlie social order, then blame and punishment are practices that maintain deformed social orders, where economic injustice and other forms of discrimination prevail. Those orders violate the principles of freedom that ground genuine ethics, rather than protect them. ${ }^{9}$ Under conditions of inequality, legal judgments and punishments are means of maintaining privilege. Hence, Beauvoir states that she forbade herself to judge those whom society deemed criminal. Whereas punishment keeps exploitation and discrimination intact, understanding the person who committed the crime indicates a willingness to sacrifice a position of power by refusing to think of oneself as entitled to the goods that the "criminal" sought to possess.

Beauvoir returns to this point later in the essay, claiming that "it requires a lot of arrogance and very little imagination to judge another" (Beauvoir 2004, 255). ${ }^{10}$ The judge positions herself as morally superior to the person judged, refusing to see the conditions that begot the action. In fact, she considers this as a refusal to understand "the temptations a man could have faced" or "the weight of circumstances" (255). When all circumstances are considered, the agent's conduct is explainable. Once the conduct has been explained, the person is no longer seen as a criminal, or the deed becomes, to a certain degree, acceptable; its "abominable character precisely disappear[s]" (255).

Forgiveness, instead, involves judgment; blame is assigned, but rather than punishing the person, one exonerates him. Yet pardon problematizes our standing to blame: when issued in the spirit of Christian values of redemption, it assumes that humans, born of sin, are never in a position to judge one another. In such cases, forgiveness replaces legal or political judgment; we forgive, since we are not in a position to judge. But forgiveness is also presented as an alternative to punishment, for sinful humans are also in no position to punish. Unlike parents, who can forgive their children, but still punish them for their wrongdoings, what is at stake for the Christian is pardon, the deliberate avoidance of punishment (which only God can deliver).

In yet other cases, our standing to blame is not questioned, and therefore agents are judged and held accountable for their deeds. However, rather than being punished, they are reeducated and guided toward a broader understanding of their agency; this is deemed a just framework for addressing crime (Beauvoir 2004, 256). Forgiveness can be motivated by the realization that people often fail to see the full meaning (and consequences) of their deeds. Beauvoir gives the example of members of the Hitlerjugend as agents who were not fully aware of the meaning of their actions. Treating the future as distant, they did not fully understand how their actions affected it. As children, she will later argue in Pour une morale, the young Nazis needed to be "taken in hand" (Beauvoir $1948,141)$ and initiated into freedom. Replacing blame and punishment with forgiveness and reeducation also invokes human life as future-oriented, so much so that freedom, which defines human life, is never entirely defined by its past. A person is 
intrinsically able to "redeem himself" (Beauvoir 2004, 257) by accepting responsibility for the deed and turning toward a new, morally defensible future of commitment to others.

In Pour une morale Beauvoir argues that being caught in the thickness of time, the Hitlerjugend were unaware of the full consequences of their actions and so although they were "responsible" for them, they are "not guilty" (Beauvoir 1948, 98). ${ }^{11}$ At the same time she adds that in the midst of a struggle against oppression there is no time for the slow labor of education, and one is "obliged to destroy not only the oppressor but also those who serve him, whether they do so out of ignorance or out of constraint" (98). Violence toward oppressors and their collaborators-guilty or innocent-is called for, then, by the extreme circumstances of the struggle. Here neither excuse nor pardon appear as justified responses to crimes; instead there is the curious imperative to punish without blame.

How should we understand the shift in Beauvoir's position? In Pour une morale, she inhabits the perspective of the oppressed (the colonized, women deprived of basic rights) and conceives of violence-the destruction of the oppressor-as an almost visceral response to subjugation. From this perspective she later condemns the prohibition of violence for girls in Le Deuxième sexe. This prohibition results in "a terrible frustration" for girls, who are unable to express "their will for power . . for competition" (Beauvoir 2011, 343) and their active vitality more generally. Beata Stawarska connects Beauvoir's position in Le Deuxième sexe to her "horror of social subjugation" (Stawarska 2020 , 6), reminding us that Beauvoir's evaluation of violence in this context is a response to an enduring social and cultural order that constitutes women as docile and passive and then discriminates against them because of those qualities. ${ }^{12}$ In this case, as in the example of the response to the Hitlerjugend members, subjugation ought to be met with the victim's violent self-affirmation, "an anger or revolt that... exert[s] itself in muscles" (Beauvoir 2011, 343). This explains that strange position expressed in Pour une morale, of punishment without blame. What is at stake is not punishment per se. Instead, violence against oppressors should be conceived of as visceral acts of revolt. ${ }^{13}$

Beauvoir's position in "Eil pour œil" is different. She writes after the war and stresses that in this context, and more generally in the legal and political contexts of punitive practices, "the relationship of the two parties facing each other is not one of struggle" (Beauvoir 2004, 247). Legal and political judgments are not made with the urgency produced by concrete subjugation, and the question of the legitimacy of blame and punishment should not be thought of under the guise of an immediate, corporeal expression of vitality, which is a "natural," albeit violent, response to oppression, as conceptualized in Pour une morale and Le Deuxième sexe. The manner in which punishment addresses the other, even if the other is an enemy who has humiliated you, is not to be considered through the paradigm of struggle, where violence is an almost automatic expression of autonomy in the face of attempts to eradicate and suppress it.

In "Eil pour œil" there are clear cases where punishment and even blame are unjustified. When the conduct under consideration is the outcome of social injustice, or is explainable in some other way, the crime can be excused and blame and punishment avoided altogether. Yet Beauvoir suggests that even if one is blameworthy, forgiveness is a more proper response: it keeps the culpable agents within the social body, as members whose future is open, who can redeem themselves through future action. As such, it encourages agents to actively assume responsibility for their deeds and rehabilitate 
themselves. When, on the other hand, one passively suffers punishment and is cast outside the social body (classified as "dangerous," jailed and excluded from the open society, or executed), the active and free element of the person's existence is severely circumscribed.

\section{Standing to Blame and Punish: The Case of Absolute Evil}

Nonetheless, blame and punishment seem unavoidable in cases of absolute evil-a category that designates moral abominations that seem unfathomable and unforgivable. Such are the deliberate and repeated attempts "to degrade man by reducing him to a thing. .." (Beauvoir 2004, 257). Beauvoir includes in this category cases of systematic offenses against others, rather than random or isolated acts of violence. Two forms of judgment, retaliation and retribution, are presented as potential responses to absolute evil, but Beauvoir finds both inadequate. In fact, the notions of justice underlying retaliation and retribution lead to the failure of these judgments and the impossibility of thinking of them as valid responses to crimes.

Revenge and "sanctions" (251), or retaliatory and retributive judgments, are required when understanding and forgiveness are no longer viable options. Absolute evil threatens the very social order in which human actions are grounded and in which concepts such as "the good" and "the valuable" draw their meaning. ${ }^{14}$ Actions that constitute absolute evil preclude understanding; they simply do not partake in the shared world that renders human action intelligible. This fact distinguishes absolute evil from ordinary crimes. However contemptuous the actions of thieves and murderers are, they are still fathomable as responses to existing social values, even if they violate such values. They are actions whose meaning can be challenged or accepted, negotiated and debated. Unlike moral transgressions, absolute evil compromises the political world in which differing views and actions are negotiated, for it attacks human freedom, the ground of every value and action. Because of this, an intelligible world of shared meaning cannot be the starting point for explaining or understanding absolute evil. The question remains whether and in what way an intelligible world can be the foundation for justifying retaliation and retribution.

According to Beauvoir, retaliatory and retributive judgments are issued from within the world threatened by absolute evil. Judgment upholds "our values, our reasons to live," says Beauvoir (Beauvoir 2004, 246), who identifies as part of a human collectivity that transcends French or European specificity. "Our" values are the values of "the human community" (246), whose members share a respect for human dignity. Beauvoir's description of the rebuilding of French society after the war as a society that "refuses tyranny" and "strives to reestablish the dignity of man" (246) shows that there is nothing French about the newly formed, postwar society. It is committed to the freedom of the French citizen qua person. Beauvoir distinguishes between the community as a social and national entity and the community as an ethical entity. Although she still criticizes the specific social configuration of the French state, she upholds it as an ethical community that recognizes the humanity of all of its members-rich and poor, Jews and non-Jews alike. ${ }^{15}$

Although retaliatory and retributive judgments are intended to maintain broad human values, not everyone is in a position to issue them. Only the immediate victims of absolute evil are in a position to take revenge. At this point the contradictions underlying these judgments emerge. The particularity of the relationship between victim and perpetrator prevents the former from generating judgments. But judgments that ground 
their contents in universals fail to fulfill the goal of blame and punishment-a genuine condemnation of a particular crime and the establishment of a fitting punishment. Hence, whereas revenge is ultimately too specific a relationship to generate judgments, retribution is too abstract a position to legitimate the judgments that it generates.

\section{The Failure of Revenge}

"Eil pour cil" opens with a description of the hate that took hold of the French psyche and, according to Beauvoir, made everyone who shared the sentiment complicit in the judgments of the war tribunals. However, in postwar France, hate also motivated the "purge"-individual, unofficial acts of revenge that were neither supervised nor controlled. ${ }^{16}$ Thus, it is with a sense of urgency that Beauvoir asks if punishment is well-founded and whether the need to punish can be satisfied.

Beauvoir draws the logic of revenge from the biblical law of retaliation: "an eye for an eye, a tooth for a tooth." This victim-centered code of justice demands that the penalty match the offense in degree and kind. In this spirit, Beauvoir explains her refusal to sign the petition in favor of Brasillach, a refusal that in this particular case led to her support of the death sentence: "It was with these friends, dead or alive, that I felt solidarity; if I lifted a finger to help Brasillach, then it would have been their right to spit in my face" (Beauvoir 1992, 21). They would have been wronged, unless a punishment that equaled the harm that they had suffered had been inflicted on him.

Yet the logic of retaliation does not justify judging on behalf of another, for two separate reasons. First, revenge equates justice with harming the wrongdoer in order to restore moral equilibrium; in other words, the perpetrator's suffering must equal that of the victim. According to Beauvoir, only a symmetrical reversal of the positions of victim and perpetrator can eradicate the evil from the world, the evil being the wrong that was done to a specific victim. The reality in which one subject infringes on the freedom of another must be canceled, and this is possible only if victim and offender exchange positions-the victim must affirm her sovereignty; the offender must experience passivity and vulnerability. Therefore, the victim, and not a proxy, must act as judge and executioner. Only the victim's violent affirmation of his or her subjectivity vis-à-vis the one who tried to deny it can constitute genuine reciprocity.

Altering the subject-object position leads to the "affirmation of the reciprocity of interhuman relations," which is "the metaphysical basis of the idea of justice" (Beauvoir 2004, 249). ${ }^{17}$ But more is at stake here than just reciprocity, in which one moment follows another in a logic of reaction. It also affects mutual recognition, whose moments are concurrent. One's freedom can be recognized only by an other who is simultaneously recognized as free. Thus, freedom is dependent on mutual recognition, which constitutes, affirms, and valorizes subjectivities as interlaced. This point is made clear in Pour une morale, "the recognition of the freedom of others . . . is even the condition of my own freedom" (Beauvoir 1948, 91). The subject's self-respect, her awareness of her own freedom, begets a demand for the respect of the other. Yet selfrespect is intimately linked to the respect that one receives from others. Systematic oppression and denial of freedom can lead to the degradation or even the annihilation of one's self-respect. In Pour une morale, Beauvoir argues that slaves and oppressed women have diminished self-respect or none at all. They are like children, she argues, in being unaware of their freedom, which has been denied by their masters, and they consequently have no venues to explore and pursue it. Ignorant of their freedom, they cannot, and do not, demand that others recognize it. ${ }^{18}$ 
Since the actual harm that one seeks to avenge is the violent refusal of recognition, only the victim whose subjectivity was denied, who was refused recognition, can effectively reverse the situation and demand, forcefully in this case, what was taken from her. ${ }^{19}$ Beauvoir describes the immediate response to the evil of denial of freedom as hate. As an immediate response, hate is not an affect that accompanies a rational judgment that finds an agent blameworthy. Hate is the manner of assigning blame, and it serves as the justification for punishment. One can understand or pardon the crimes of thieves or murderers. In these cases, understanding places a moral injunction on judgment, and pardon prohibits punishment. Absolute evil, on the other hand, is beyond understanding and cannot be forgiven. Yet, unlike veritable judgments that, according to Beauvoir, involve "a reflective act of will" (Beauvoir 2004, 258), hate is not mediated by reflection, concepts, or second-order deliberation. It "calls immediately for . . revenge" (248). In hate, blame is bound up with the necessity of sanction-in this case, a punishment that equals the harm of the offense.

Hate, in this context, is neither blind nor capricious (248). It is a moral sentiment that responds to an abomination. Kruks, who discusses hate as an alternative model of political judgment, replacing cognitivist conceptions of judgments as rational decisions, interprets it as "an existential choice" (Kruks 2012, 149). This choice, although expressing emotions, habits, and personal histories, is not determined by them. As such, hate is a personal act, rooted in and reflecting the life of the subject. Indeed, Beauvoir seems to hold that the hate is valid as grounds for blame and punishment only if it is expressed by one individual directing it at another, from victim to perpetrator. "Hate," she says, "wants to strike the criminal at the heart of his evil activity" (Beauvoir 2004, 253).

Again, Beauvoir thinks of hate, a sentiment by which blame is assigned, as a quasijudgment validated by the desire for recognition. Yet does the hateful violence that the victim feels toward the perpetrator constitute judgment? "Vengeance is a concrete relation among individuals," says Beauvoir, comparing this relationship to "struggle, love, torture, murder or friendship" (251). If revenge is like these other relationships, as Beauvoir's description of it as immediate, emotive, and personal seems to imply, then in what sense can it function as a judgment? Can it validate blame? Perhaps just as love could be taken to express a claim about the love-worthiness of its object, hate could be taken to indicate that the perpetrator is hate-worthy, culpable. But love is object-directed, and the object seems to determine the emotion and the actions that one takes toward it; revenge, on the other hand, is victim-centered, and the grounds and measure for its "judgment," for the hate, is the harm caused to the victim. Hence hate, if it is to function as judgment, must reflect back on the harm done to the victim and, in a secondary act, tie it to the offender. This is beyond what hate can accomplish. It is certainly a meaningful way in which victims position themselves vis-à-vis perpetrators, and at times it is a justified emotion and response to harms, but this does not render it a judgment, an act by which blame is assigned, or make it a justification for the punishment that follows. Beauvoir seems aware that revenge in its proper manifestation as a victim-perpetrator relationship does not constitute a judgment at all when she says that "revenge expresses the passions of the moment instead of manifesting a reflective act of will" (258). She makes the distinction between feelings and second-order evaluation of these feelings in judgment.

Revenge, in the narrow and precise sense of the word, is not a judgment. It is legitimized in the "privileged case," wherein the victim responds viscerally to the oppressor who crushes her, for instance, when concentration-camp inmates murdered 
their S.S. jailers at the moment of liberation. Examples of such privileged cases also appear in Pour une morale in the discussion of revolt and resistance to oppression. Indeed, there Beauvoir describes oppression as "hateful" (Beauvoir 1948, 82) and argues that the only "solution" to it is "revolting against the tyrants" (83). In this limited context, revolt is structured as revenge, as it aims to reverse the positions of oppressor and oppressed. Yet rather than assigning blame through an act of judgment, violent revolt is portrayed as an automatic release of blocked energy. In Le Deuxième sexe, she welcomes revolt since it discloses that the oppressed has not yet fully internalized their objectification by the oppressor. The violent expression of subjectivity through revolt is compared with the docility of the woman, who, prevented from exploring the world through her body, passively submits to her oppression, and accepts it as a given. ${ }^{20}$

The starting point in "EEil pour œil" is not that of immediate response to oppression. There, the question is not the status of revolt, but how and if blame and punishment can be justified retrospectively. Focusing on our standing to blame and punish, she moves away from phenomenological description to normative claims and argues that "as soon as the avenger aspires to set himself up as a judge, vengeance becomes suspect" (Beauvoir 2004, 251). Under consideration are retaliatory judgments-revenge in its generalized form. This form cannot be grounded in the victim-offender relationship. As long as one responds from the position of victimhood one is not a judge; hate, in this case, is an understandable emotive response, but one that does not constitute a judgment.

As we saw, only victims can reclaim their stolen sovereignty. Nonetheless, as a code of justice, retaliation provides a principle from which judgments ought to follow. Others ought to be able to assign blame on the victim's behalf in accordance with this law when, for example, the immediate victims of the crime are dead or otherwise unable, or unwilling, to demand a reversal of positions.

In such cases, Beauvoir argues, blame rests on the postulation of an essence, shared by both judge and victim: "A stranger can intervene only insofar as he participates in the universal essence of man that has been injured in the victim" (251). In other words, what enabled Beauvoir to blame was the assumption that she and the victim were alike; she and her friends were equally human, experiencing their humanity, subjectivity, and freedom in identical ways. Because of this, she is authorized, so to speak, to claim the recovery of their autonomy by calling for a punishment for their offender.

Defending this position, Kruks stresses the claim, in itself accurate, that our lives are interwoven with the lives of others, and so our responses to their pain are visceral and emphatic. However, as we saw, Beauvoir distinguishes judgment from what Kruks calls "a visceral or 'gut' response to the suffering of others" (Kruks 2012, 164). Although these responses may motivate judgment, they do not in themselves constitute judgment, which is a second-order act, according to Beauvoir herself. Moreover, in seeking revenge on behalf of others, one assumes the right to demand respect for them. This right is based on the presumption that one can have access to victims' inner experiences of the offense, as well as their responses to the harm. That is, the right is based on the belief in the universality of human experience. Recall that retaliatory judgments are victim-centered, and hence, whoever assigns blame issues the judgment from the victim's perspective and for the victim's sake. However, human experience is not universal; it is impossible for others to inhabit the victim's position in a manner that will legitimize a retaliatory judgment. ${ }^{21}$

According to Beauvoir, a person who avenges the violation of another's humanity "becomes himself a tyrant" (Beauvoir 2004, 251): a tyrant, since the person assumes 
the position of ultimate sovereignty, a position that refuses to admit the opaqueness of the victim's experience. Moreover, in claiming to wholly inhabit the victim's experience by virtue of a subjective essence that victim and judge are thought to share, the judge is at risk of failing to acknowledge the ways in which he might be invested in the quest for revenge. Consequently, retaliation, as a system of justice distinct from acts of revenge performed by victims, as a set of principles that guides judgment (as opposed to a sentiment, or a moral feeling) fails. It is either a relationship between individuals and, consequently, too concrete and singular to guide, ground, and constitute standing to blame and punish or, when the relationship is generalized, for the purpose of issuing judgments, the result is that one loses the right to blame.

\section{From Revenge to Retribution?}

After examining the failures of revenge, in its one-to-one privileged form as well as in its more generalized configurations, Beauvoir examines the possibility of grounding blame in a different system of justice, "social" or "organized justice" (Beauvoir 2004, 252). With the transition to this form of justice, society aims to rid itself of the unjustified violence embedded in revenge. But the judgments of courts and war tribunals are not merely sublimated revenge. These judgments are anchored in a different logic, that of retribution, which "no longer seeks to reestablish an impossible reciprocity" (251). Retributive justice is not centered around the victim; its judgments focus on the offender's culpability in violating the principles of justice, rather than the harm the offender inflicted on the victim. Put differently, retribution operates under the assumption that justice, not revenge, requires that the culpable agent will suffer. Beauvoir claims that the aim of retribution is "to eliminate the guilty from society" (251). What I take her to mean is that retributive judgments focus on the responsibility of agents for their crimes, in this sense seen as guilty and worthy of punishment.

Phenomenologically, revenge is backward-looking, grounded in the harm that was done to the victim, whereas organized or retributive justice is future-oriented. By assigning blame, the judges "refuse in the present, for the future, in the name of the whole society, this wrong that cannot be effaced" (252). Since it does not follow the logic of retaliation, retribution admits that the harm done to the victim cannot be effaced-an eye cannot be substituted for an eye-and the aim of punishment is not to eradicate the violence of the crime. Instead, past wrongdoing is punished for the sake of the future. Yet this is not because the punishment has a particular utilitarian value, such as deterring others from committing similar crimes, but rather because it is intrinsically good for perpetrators to suffer punishment. Hence, when Beauvoir says that the aim of the judgment is "to restore a human community to its own idea of itself, to uphold the values that the crime has negated" (252), the good that retribution aims at is not extrinsic but intrinsic to its judgments. What is restored are the moral values in which retribution is grounded and that it aims to uphold: for example, principles of right and good. ${ }^{22}$

Since retributive judgment focuses solely on the agent's responsibility for violating justice, it distinguishes "the man and the criminal" (252), unlike revenge, where the two are "confounded" (252). The person is blamed qua criminal and is not implicated in his or her entirety by the act. Beauvoir argues that this was taken to its extreme with the decision to commute Pétain's death sentence to life imprisonment. In this particular example, Pétain the traitor was distinguished from the old man standing trial-the first condoned, the second pardoned. With the passing of time, it seemed unjust to punish 
the old man for the deeds he committed during the war. Moreover, the judicial setting detaches the person on trial from crimes that he committed. The person does not appear as a "criminal at the heart of his evil activity" (253). The "dissociation" of person from criminal seems to coincide with the existential refusal to think of subjective life through the lens of determinism. Beauvoir describes how the judges turn away from the criminal's past, because they know it is beyond their reach, inasmuch as the person on trial is irreducible to the person who committed the offense in the past. Once past and present are not enmeshed with each other, the decision to convict and punish is formed "without hate" (254).

Indeed, institutions do not have emotions, and thus a retributive judgment issued by a court is "cut off from its base in the passions" (251). This is in direct opposition to retaliatory judgments that are motivated by hatred of the victimizer. Retribution is also cut off from emotion by not resulting in pleasure, whereas the hate and anger that motivate revenge entail a kind of pleasure at the suffering of the wrongdoer.

Although retribution avoids the pitfalls of revenge, including the inability to reestablish reciprocity between offender and victim, and the failure to legitimize its recourse to blame, Beauvoir thinks that retribution fails. By disconnecting blame from utilitarian ends - the satisfaction of hatred in acts of vengeance being one such desired resultretributive justice risks dissociating the crime from the punishment, so that punishment seems "an arbitrarily imposed penalty" (254). Vengeance ties the punishment to the crime through the law of "an eye for an eye." But retributive justice gives up on this principle without offering an alternative way to justify punishment. Thus Beauvoir argues that it ends up producing vacuous ceremonies, and she describes "the pomp of big trials, their tragic dimension, their ceremonial rites" (253). She mentions in this context "the impotent protestations the European democracies made before 1939 against crimes that were all too real" (252), referring, perhaps, to the Évian conference, where participating states acknowledged the plight of the Jews in light of increasing persecution by the Nazis, but failed to take measures against the aggressors. Where no punishment is inflicted, blame seems futile.

Sometimes, however, blame matters more than punishment. This is Beauvoir's view regarding the decision to commute Pétain's death sentence. The act of blame matters because it enables civil society to position itself vis-à-vis the crime and hone its values through condemnation. She makes a similar point in Pour une morale, where she returns to the hesitations of the courts and their long, drawn-out trials. Although the urgency of punishment, particularly in traumatic postwar situations, seems at odds with long, formal debates in courts, Beauvoir now seems to value judicial theatricality and its ability to dissociate blame from punishment. Judicial ceremonies enable society to rebuild itself after the crisis of war, when it "had to resort to blind violence" (Beauvoir 1948, 107). Forgoing violence, it is able to restore human dignity and civility. In other words, society steps away from blind violence by replacing the logic of retaliation with retribution, by refusing to ground retributive judgments in emotions and by emphasizing their formality, and finally even by stressing blame over punishment. The aim of such steps is to restore respect for justice, as the ultimate refuge for all humans, who must learn again what it means to be citizens, part of the social world. ${ }^{23}$

Nonetheless, in "CEil pour œil," Beauvoir holds that retribution lacks justification. With their focus on the restoration of justice, the courts ignore the harm suffered by individuals and fail to connect perpetrator and victim. Retribution thus separates "principles and reality" (Beauvoir 2004, 258). The general principles that guide retributive judgments are blind to the particularity of the offense, and the transition from the 
universal level of the law to the individuality of the victim and perpetrator cannot be effectively achieved.

\section{Punishment, Violence, and Freedom}

"Eil pour œil" brings into relief the irreconcilable tension between the desire to condemn absolute evil by blame and punishment and the possibility of justifying the desire through retaliation and retribution. The desire to punish is underscored by a normative demand: "we must still want the punishment of authentic criminals" (Beauvoir 2004, 259, my emphasis). We ought to demand punishment, because through it we recognize "man as free" (259). Freedom is the motivating force of both retaliation and retribution: retaliation aims to restore the victim's freedom; retribution upholds the culpable as free and hence worthy of punishment. Nonetheless, freedom prevents punishment from attaining its goals, and thus it is freedom that stands in the way of wholeheartedly endorsing it.

Freedom "protrudes"; it obstructs attempts to justify punitive measures, even in cases of absolute evil. In the case of retaliation, the perpetrator's freedom hinders revenge from achieving its goals. The intent of vengeance cannot be satisfied, because consciousness must be free in order for the punishment to be effective (we want the person to realize the wrong), but a free consciousness can always refuse to repent and undergo its punishment "with a sense of irony, with resistance, with arrogance, with a resignation lacking remorse" (250). With retribution, the freedom of the criminal problematizes the motive for punishment. In a rather Kantian fashion, Beauvoir suggests that retribution is grounded in respect for wrongdoers, that is to say, respect for their free agency. ${ }^{24}$ Yet if respect for the perpetrators motivates punishment, then they cannot be treated as a means for the achievement of some other goal. Hence, the punishment cannot aim to deter or prevent future crimes (although it can inadvertently achieve this goal). But more than that, if the agent is free, punishment becomes suspect, for reducing the person to past wrongdoing is a refusal to admit that "freedom, although always bound up with the past, is never held captive by it" (256). ${ }^{25}$

Grounding blame and punishment in freedom, Beauvoir connects these practices to the chief principle of ethical life: the commitment to freedom. Nonetheless, this commitment, which motivates blame and punishment and serves as their goal, leads to "a real spilling of blood" (254). It results, in other words, in violence; it deliberately leads to a degradation of others by imprisonment or death. ${ }^{26}$ Turning now to Beauvoir's account of ethics in Pour une morale, I argue that punishment as a form of violence cannot be normatively defended. In other words, punishment, which aims to restore and safeguard human ethical life-by upholding freedom as a value-cannot, by this very ethic, be justified.

In "EEil pour œil," Beauvoir refers to the violence of absolute evil as an absolute event. $^{27}$ As an event, evil disrupts and suspends the situation in which it appears. As absolute, it cannot be fathomed according to the categories with which we approach and inhabit the world; there are simply no standards of sense with which we can understand it. In Pour une morale, Beauvoir describes such evils-the deliberate use of one's freedom to deny the freedom of another-as "outrageous" (Beauvoir 1948, 97). ${ }^{28}$ The evil is "itself so outrageous that the outrageousness of violence which one practices against it is almost cancelled out..." (97). It is crucial, I think, that in the final balance, the outrageousness of the counter-violence is only "almost" canceled out. ${ }^{29}$ This "almost" could be indicative of what Ann Murphy calls "moments of ambiguity" (Murphy 2012, 102) - a fundamental uncertainty that prevents the formulation of a 
definitive ethics and stable principles of right and wrong. Murphy takes this ambiguity to be productive, generating in the agent a sense of responsibility and a refusal to take shelter in absolute values. She is right, of course, inasmuch as Beauvoir insists that the human condition is ambiguous and genuine living requires that "man must not attempt to dispel the ambiguity of his being but, on the contrary, accept the task of realizing it" (Beauvoir 1948, 13).

But Beauvoir does speak of a "genuine moral attitude" (Beauvoir 1948, 59), and a "genuinely free man" (61), distinguishing such attitudes and individuals from their false counterparts. Moreover, she discusses principles that guide moral agents and define moral attitudes, thus giving a positive, definite characterization of ethical life: "An ethics of ambiguity will be one which will refuse to deny a priori that separate existants can, at the same time, be bound to each other, that their individual freedoms can forge laws valid for all" (18). ${ }^{30}$ Hence, ethical life is unambiguous at least to a certain degree; there are laws that bind together the plurality of separate human beings.

Those laws are explicitly addressed in the ethics: being moral entails recognizing and upholding one's own freedom. ${ }^{31}$ Morality requires a reflective assumption of freedom; one must become aware of her freedom and assume it as a value. Once the subject recognizes her freedom, she ought to realize that "the freedom of other men must be respected" (Beauvoir 1948, 60). ${ }^{32}$ Beauvoir explicitly says that this law "imposes limits upon action and at the same time immediately gives it content" (60). Consequently, an ethics of ambiguity is not ambiguous about the need to affirm freedom.

Being human does not place the person automatically within the ethical, according to Beauvoir. Children, for example, are amoral creatures, unable to "decide and choose" (Beauvoir 1948, 27). Because children are unaware of their freedom, they are not expected to recognize and uphold it as a value; "no moral question presents itself to the child" (27). As we saw, Beauvoir thinks that some adults are psychologically infantile, because society has kept them in a state of servitude and, in their case, "ignorance and error are facts as inescapable as prison walls" (38). In these cases, ignorance and error are not judged as morally faulty, because the agents have not yet entered the sphere of ethics. Even characters such as the sub-men, who, Beauvoir holds, are treated as moral agents, are liminal figures seemingly on the verge of the ethical. The sub-man's project is to mask his own freedom; he tries to turn himself into a brute fact, wholly defined by external circumstances over which, he believes, he has no power and which he must therefore obey. Although his behavior still manifests an awareness of freedom from which he is trying to flee, this awareness is so minimal, buried in the depth of the insipid life he tries to live, that he can barely be said to uphold or reject freedom as a value, as the ethical person does. The sub-man's life is devoted to the attempt to avoid the transition from nature to ethics; even his resistance to freedom is "inert" (38). ${ }^{33}$

Rather than moral condemnation, the sub-man arouses contempt and disgust. ${ }^{34}$ Lacking self-respect, he is perceived as a despicable thing, an object-like creature. "Ethics is the triumph of freedom over facticity, and the sub-man feels only the facticity of his existence" (Beauvoir 1948, 44), says Beauvoir, thus locating the sub-man on the threshold, as not entirely moral. The insistence that the behavior of the sub-man is not to be evaluated in ethical terms is crucial to our point, since the sub-man is the one who often commits moral atrocities. ${ }^{35}$ If his actions are not worthy of moral condemnation, then blame and punishment, through which ethics is made manifest in political life, might not be the proper ways of responding to his acts.

Entrance into the ethical is contingent upon an explicit affirmation of freedom: "To will oneself free is to effect the transition from nature to morality by establishing a 
genuine freedom on the original upsurge of our existence" (Beauvoir 1948, 25). Freedom is (at first) an ontological feature of human consciousness; being free just means being conscious-withdrawing from the plenum of being, distancing oneself from everything of which one is conscious, by virtue of not being a thing. Because freedom manifests itself through conscious activity, it is neither ethical nor unethical. This is pre- or a-ethical activity, the activity of the disclosure of being. This level of freedom pertains to every human being, simply by virtue of being human. It conditions human life, and defines those who are not yet moral, like children. Morality is born once this freedom is chosen as a value. ${ }^{36}$ Only when humans move from being freedom to willing freedom can they be said to be moral. The transition entails choosing ontological freedom as a guiding principle, one that defines life. This choice amounts to an affirmation of freedom-the realization that all values are human-made-and its election as a guideline for action through a commitment to the creation of a world in which freedom is itself a value, a world in which others are able to realize and affirm their own freedom.

The ethical laws that Beauvoir develops in Pour une morale do not provide positive content to freedom, but they do define its limits. Thus, it is clear that a project is not genuinely moral if its pursuit involves obstructing others from carrying out their projects. Deliberate attempts to thwart the freedom of others are immoral because they use freedom to diminish freedom. Such are the actions of the criminal and the tyrant, who affirm their own freedom at the cost of the freedom of others. Hence, criminals and tyrants are those who have entered into the ethical-their actions reflect deliberate choices-and precisely because of this their choices are morally condemnable.

The criminal is free even after he violates the principles of freedom, even after his assault on the ethical life of the community. Only because of his freedom is he worthy of moral evaluation. Thus, punishment aims to restore freedom by violating freedom. In justifying punishment, one inhabits two conflicting perspectives: commitment to freedom, which is both the ground and the telos of blame and punishment, and suspension of freedom in pursuit of punishment, which is, as a violent violation of freedom, outrageous (Beauvoir 1948, 97).

Punishment both upholds ethics and suspends it. Phenomenologically, the stance from which we issue retaliatory and retributive judgments is rife with tensions, and Beauvoir's account in "Eil pour œil" is attentive precisely to the paradoxes that result from this position. From yet another direction, I suggest that the paradox stems from the irreconcilable tension between the phenomenological and normative perspectives. Although as ambiguous creatures we may desire punishment, as ethical subjects, who act under the unambiguous commitment to freedom, we ought not to act on this desire.

It is crucial that Beauvoir distinguishes violent acts of revolt, as immediate responses to oppression, from organized punitive practices. Whereas she thinks of the former in almost naturalistic terms, the latter are the object of moral evaluation. Even in moments when she seems to affirm violence as an "authentic" expression of subjectivity (Beauvoir $2011,343)$, as an act of self-affirmation that leaves an imprint on the world, one is left wondering about the manner in which she understands the world in which one needs to resort to violence in order to leave such imprints. Indeed, in Le Deuxieme sexe, the background to the discussion is the oppression of women, which is perpetuated by a prohibition of violence that trains them for passivity and docility. In this environment of systematic injustice and inequality, it would have been better for girls and women to have violently revolted (she also mentions the situation of "the black. . . in the white world" [343] in this context). Beauvoir describes this world as haunted by violence, even saying that "much of masculine behavior arises in a setting of potential violence" 
(343). But does this mean that violence is part of every human environment? Does it imply that we ought to endorse violence as an integral part of the human world? Rather than answering these questions in the affirmative, we should notice that this world is defined by oppression and injustice. Violence belongs to a patriarchal world. And, as Debra Bergoffen reminds us, "neither the man nor the woman of patriarchy are subjects" (Bergoffen 1997, 108). Put differently, violence is valorized inasmuch as it can enable women and other oppressed groups to stop being "others." But once all humans are no longer in the grip of patriarchy, once freedom becomes a concrete guiding principle, once, in other words, we establish a genuine ethical community, violence ought not to haunt our world. ${ }^{37}$

\section{Beauvoir and Abolitionism}

Against the dialectic of freedom and violence, Beauvoir offers the idea of absolute commitment to freedom, of each person's freedom unfurling in concordance with the freedom of others. Affirming this idea, she claims, is akin to dreaming (Beauvoir 1948, 81). Yet, she says, it is "permissible" to dream (81), ${ }^{38}$ and she never describes dreams as mere fantasy or illusion. The dream functions as an ideal, a horizon toward which human actions ought to be directed. Moreover, she speaks of a genuinely moral attitude, ${ }^{39}$ an attitude that conveys a general commitment to the freedom of all subjects.

The aporias of blame and punishment in "EFil pour œil," which underlie even responses to moral atrocities, suggest that Beauvoir's ideal of ethics necessitates an abolitionist position regarding punishment. The fact that this ideal ethics is formulated only in the negative resonates with Thomas Mathiesen's description of abolition as "the unfinished." As an alternative to state punishment, abolition is not premised on its terms, and because of this, its message remains "foreign," despite the fact that it is "fully formed," that is, the consequences of carrying it out are clear (Mathiesen 2015, 48). Hence, understanding penal abolition to be an injunction of Beauvoir's ethics is consistent with her delineation of this ethics around a mostly negative ethical horizon of freedom.

As mentioned in the introduction, the contemporary abolition movement is quite heterogeneous, and spans specific struggles for prison abolition and broader calls for penal abolition and the elimination of the prison industrial complex, an institutional and political matrix that extends beyond prison walls (Davis 2003). Although I cannot discuss these different goals and foci here, I hope that the proposed interpretation of Beauvoir's work leads us away from individualistic and liberal conceptions of crime and responsibility toward a more radical abolitionist agenda that interrogates the notions of "crime," "harm," "victimization," and "punishment," and seeks to rethink the paradigmatic frameworks of criminal justice.

More specifically, my interpretation of Beauvoir's work resonates with abolitionist ideas in two ways. First, an analysis of Beauvoir's account of the prewar criminal justice apparatus reveals that she does not reify crime, but understands it as a name given to acts prohibited and punished by the state. Thus, it is state power and its criminal justice institutions, which embody racist, patriarchal, and capitalist ideologies, that need to be examined. In this respect, Beauvoir reminds us that the call to abolish punishment goes hand in hand with the radical transformation of state institutions and social practices that are beyond the realm of penalty. We saw that the prewar judicial system was not impartial; it assigned blame and punished according to the interests of the liberal state, which perpetuated injustice and worked in the service of privilege. Beauvoir explicitly mentions her own privilege in this context. ${ }^{40} \mathrm{Her}$ discussion points to the 
fact that a structural change is necessary to combat this inequality. Existing punitive strategies fail to bring about social change. In the case of ordinary crimes, punishment, and at times even blame, perpetuates injustice by affirming and consolidating exploitative and unjust social orders. In such cases, punishment ought to be circumvented and, more radically, blame must also not be assigned. The call to abolish legal and carceral institutions is congruent with contemporary feminist abolitionist frameworks, which point to the active role that such institutions play in determining who is a "victim" and who is an "offender." Discerning the two is done along racial, gendered, sexual, and class lines (Whalley and Hackett 2017, 469) and thus perpetuates rather than eradicates oppression.

But something different is at stake for Beauvoir in the case of absolute evil, which deliberately seeks to destroy the fabric of the social world. Absolute evil demands blame, necessitates acts that distinguish offender from victims. Yet even then, Beauvoir's position entails that we reconsider the uninterrupted transition from blame to punishment. A commitment to freedom, to its restoration in the world, renders punishment an impossible project. Restorative justice is a viable alternative response to wrongdoing, one that does not implicate blame in the paradoxes of punishment. In restoration, offenders can still be held guilty and condemned for the deliberate violation of human freedom, from which all values spring. ${ }^{41}$ Yet nonpunitive responses to atrocities focus on both victims' and perpetrators' freedom in a truly Beauvoirian manner. They enable victims to affirm their subjectivity by letting their voices be heard and narratives vindicated, and they enable offenders to assume responsibility for their crimes, encouraging the use of freedom in the spirit of an ethics of freedom and not against it. It is crucial, in this context, that Beauvoir thinks of "absolute evil" beyond the scope of the deeds of individual offenders and relates it to the fabric of the community in which it appears as well as to the experience of those who undergo it. Moreover, in her account, the identities of victims and offenders remain open-ended; she refuses to ossify subjects and insists that human action can inaugurate a future of social equality, freedom, and solidarity, even in the face of war, trauma, and injustice. Chloë Taylor points out that the truth and reconciliation commissions home in on criminal acts, rather than on individual pathologies or personalities needing to be managed. Although individuals are held accountable and the victims' trauma is acknowledged, the strategy of the commissions is to involve offenders and victims in social transformation (Taylor 2009, 21). Beauvoir's ethics, where genuine action is free, offers a justification for abolitionist alternatives to punishment, and helps us reconceptualize how we understand and relate to the oppression of victims, offenders, and communities. ${ }^{42}$

Acknowledgments. I thank Daniel Statman, who, after reading an earlier draft of this essay, made time for a stimulating conversation about blame and punishment. His ample feedback, challenges, and suggestions were immensely valuable for my own thinking on these matters. I thank Yoav Mehozay for providing useful references to literature on abolitionism. Finally, I wish to thank Bonnie Mann, the co-editor of Hypatia, and the referees, for their careful reading, comments, and timely responses; all are very much appreciated. Research for this essay was supported by the Israel Science Foundation (grant 1990/19).

\section{Notes}

1 Beauvoir's phenomenology of vengeance is studied by Kruks 2012; La Caze 2018.

2 "Freedom," says Beauvoir in Pour une morale, "is the source from which all signification and all values spring" (Beauvoir 1948, 24). In this respect, freedom grounds ethics. But for Beauvoir, freedom is not only the source, but also the end of ethics. As I will show, the relationship between ethics and freedom renders 
vulnerable our standing to blame. In Beauvoir's account, retaliatory and retributive judgments suspend the ethical, or the commitment to freedom. Although their purpose is to uphold ethics and freedom against violation, they can perform this task only from outside the ethical, not from within.

3 "scandaleux" (Beauvoir 1946, 824).

4 The tension between the necessity for blame and the difficulty of justifying punishment is also manifest on the biographical level of Beauvoir's work. The impetus for writing "CEil pour œil" was Beauvoir's own experience of the Brasillach trial and its aftermath: his execution following unsuccessful circulation of a petition among French intellectuals for clemency. Beauvoir was personally involved in this affair-she refused to sign the petition-and she discussed her refusal in "CEil pour œil" and again, more elaborately, almost twenty years later, in her autobiography La Force de l'âge. There, Beauvoir stands behind her decision, saying that she wholeheartedly refused to sign the petition and has never regretted it (Beauvoir 1992, 21). Yet when she wrote about the issue immediately after the war, in "EEil pour œil," she was much less decisive. "It is for these reasons that I did not sign the pardon petition for Robert Brasillach" (Beauvoir 2004, 257), she says toward the end of the essay, which from that point on assumes, prospectively and retrospectively, an apologetic tone. A closer look at La Force de l'âge reveals traces of guilt in her assured tone; she writes that the petition was circulated and that she refused to sign it before the trial took place, thus underplaying her support of the execution. She remembers her resolve in refusing to sign a document declaring solidarity with Brasillach. Yet the petition was actually drafted and distributed after his conviction in court; it specifically called for commutation of the death sentence. Misremembering the nature of the petition and the moment of her refusal, she reports that "my signature carried no weight, my refusal was a mere gesture..." (Beauvoir 1992, 21). Beauvoir seems to eschew responsibility for her support of the execution. She cites Camus, who "had the same reaction" and affirmed that "the judges will decide; it's their business, not ours" (21). Nonetheless, Camus signed the petition, not for Brasillach the individual, whom, he says, he disdains with all his might (Kaplan 2000, 198), but against the death penalty. Beauvoir's forgetfulness reveals an unease about endorsing punishment, an unease that remains implicit. However, her theoretical treatment of retaliation and retribution clearly points to irresolvable tensions between the necessity for blame and the legitimacy of punishment.

5 "[W]ithout failure, no ethics," says Beauvoir (Beauvoir 1948, 10). Yet "the characteristic feature of all ethics is to consider human life as a game that can be won or lost and to teach man the means of winning" (23).

6 "[T]he joy has not risen up in our hearts," says Beauvoir (Beauvoir 2004, 246), despite her desire for revenge during the war.

7 In this respect my reading differs from Marguerite La Caze's. She also examines the essay on phenomenological and normative levels, but holds that Beauvoir claims that the need is well-founded, but unsatisfiable (La Caze 2018, 24-25). Nonetheless, I am in complete agreement with her that "while Beauvoir defends these affects as essentially human, she also shows how the attempt to act on them leads to a series of paradoxes" (29). I explain the paradoxes by appealing, in the penultimate section, to Beauvoir's conception of ethics. La Caze, on the other hand, focuses on the affective structure at play in acts of revenge or sanctions and the temporality of retaliatory and retributive judgments. Although she also argues that Beauvoir's paradoxical account of punishment should lead us to reconsider capital punishment at least, she leaves open the question of other forms of punishment and, moreover, allows for the possibility that punishment can be justified by a "correct" use or training of emotions (thus resolving the paradoxes Beauvoir describes).

8 Lori Marso suggests that Beauvoir, like Arendt, understands instances of "fear of judging" to be rooted in the belief that "no one is a free agent" (Marso 2012, 172).

9 This point is made explicit in later discussions of oppression and systematic inequality. "Justice can never be created within injustice," says Beauvoir in the Le Deuxième sexe, in relation to the position of enlightened colonialists, who behave benignly toward indigenous populations (Beauvoir 2011, 759).

10 Beauvoir's view on the role of imagination differs from Hannah Arendt's. For Arendt, it is a "lack of imagination" that results in failure to judge (Arendt 1977, 237). Hence, imagination is necessary for judgment, for it enables me to consider positions other than my own in forming "my opinion" (237). My opinion is subjective, but brings with it claims to universal validity. And in order to strengthen the validity of an opinion, I am required to represent to myself other viewpoints. The issue is that Arendt seeks to imagine, or represent, the views of those with whom she seeks accord. She asks those "witnessing" the judgment to validate it. Beauvoir, on the other hand, thinks that in certain cases, judgment, even when it is validated by 
such witnesses, is necessarily uninformed by the position of the other. Judgment manifests a lack of imagination because in seeking agreement it leaves out the perspective of the people whom we judge (and not the perspective of others who issue judgments with us).

11 Beauvoir discusses a young Hitler supporter who died in the service of Nazism. He is not someone to hate (the hate is reserved for the masters, the ideologists) and should not have died, for "the desirable thing would be to re-educate this misled youth" (Beauvoir 1948, 98).

12 Stawarska also discusses "Eil pour oil" and reaches radically different conclusions from those that I present here (Stawarska 2020). She portrays vengeance as an almost therapeutic practice, in which violence reverses moral and metaphysical degradation. Thus, she argues that Beauvoir avoids a moralization of violence, which is grounded in idealistic ethics. Our different interpretations stem, therefore, from a different reading of Beauvoir's ethics. I develop this point in the penultimate section of this essay.

13 The disconnect between crime and harm anticipates the affinity between Beauvoir's position and abolitionism, which I will discuss at the end of the essay. When Beauvoir was writing, many of the harms that women suffered were not classified as crimes by the state, yet this did not affect women's experience of them as harm and suffering. From yet another direction, Beauvoir thinks that this harm, although not classified as crime, merits a response (at times even a violent one), yet it is crucial that this response is one of social activism and resistance, not an official state punishment.

14 "The word useful requires a complement, and there can be only one: man himself," says Beauvoir in Pour une morale (Beauvoir 1948, 112). An action is judged useful or useless, good or bad in relation to human projects, which are anchored in shared worlds and practices.

15 Beauvoir is aware of the privilege by virtue of which she immediately qualifies as a member of both orders, the social and the political, but does not discuss her potential complicity in maintaining the existing, unequal social order (a complicity perhaps expressed by her discussion of the two realms as separate). She seems to imply that exclusion is the outcome of sheer chance (being born to a certain class) and by the actions of "a regime that did not give everyone an equal chance" (Beauvoir 2004, 245). She does not support the regime, but still claims, after the war, "this society as ours" (246).

16 Postwar purges are described in "CEil pour œil" at length: "there have been 'barberings,' lynching of snipers, summary executions of certain of the collaborationist police, and massacres of the S.S. prison guards by their freed captives" (Beauvoir 2004, 247-48).

17 Perhaps Beauvoir means this specific system of justice, that is, retaliation, because before the war, one-to-one reciprocal relationships were not the underlying principle of justice. Beauvoir did not think it was just to reciprocate harm against the socially disadvantaged. Or if she thought that reciprocity was due, it was not to be found in one-to-one reciprocity.

18 Beauvoir defends paternalism not only in relation to children, but also in relation to oppressed women and slaves. They need to be initiated into freedom, to learn that they are subjects who must be treated as such. Because they are not aware of their subjectivity, they can be treated paternalistically. For criticisms of Beauvoir's paternalism, see Gines 2014.

19 Beauvoir discusses the inherent instability of revenge. Mutual recognition cannot be forced. One cannot violently demand that the other acknowledge her subjectivity-as the structure of reciprocity necessitatesbecause that violent demand itself violates the other's freedom. Yet it is precisely the other as free who needs to acknowledge the victim's subjectivity. The torturer must be forced to freely recognize the victim as free. The tension between freedom and coercion turns revenge into an (almost) impossible project. However, the empirical impossibility of satisfying revenge does not undermine its validity as a project, and for this reason I will not discuss this issue at greater length here.

20 A similar fate awaited those who did not resist their oppressors during the occupation: "The French who had decided not to let themselves resort to violent gestures against the occupants... felt their situation in the world profoundly overturned: depending on the whims of others, they could be changed into objects, their subjectivity no longer had the means to express itself concretely" (Beauvoir 2011, 344).

21 The victim herself could refrain from blaming because she refuses to inhabit the victim's position, or because she firmly believes that she, and perhaps others too, are not in a position to blame (holding to the Christian belief that Beauvoir describes). What justifies the other's insistence on issuing blame and punishment in her name? Recall that in retaliation the judgment is made from the victim's perspective.

22 The purpose of retribution is the restoration of justice, and so in this case, "punishment ... takes on ... [a] symbolic role" (Beauvoir 2004, 252). 
23 The scope of this essay does not allow me to consider the alleged tension between Beauvoir's negative portrayal of judicial theatricality in "Gil pour œil" and her more positive evaluation of judicial ceremonies in Pour une morale. A possible explanation would need to consider the relationship between the individual's lived experience of freedom and the social norms within which freedom is lived and expressed. Acting in compliance with such norms is inherently theatrical or artificial. Although in one sense social theatricality limits the lived experience of freedom, it also renders it possible, as it provides concrete venues through which freedom can express itself, appear in the world. Judicial theatricality is inherently connected to the theatricality of the actions that it judges, and Beauvoir's evaluation of it takes these features of judgment and action into account.

24 La Caze and Murphy both mention Beauvoir's Kantianism in respect to her denunciation of absolute evil, but do not draw the connection between this position and her views on punishment (Murphy 2011, 43; La Caze 2018, 27).

25 This realization is the underlying principle of retribution, which does not confound "the man and the criminal" (Beauvoir 2004, 252).

26 Here I part from La Caze's account of Beauvoir's paradoxes of punishment. La Caze reads "CEil pour œil" together with Pour une morale, but does not focus on how punishment in general violates Beauvoir's ethics. She holds that Beauvoir's deep ambivalence toward the death penalty in La Force de l'âge reveals that she is closer to abolition than to a defense of the death penalty (La Caze 2018, 40). This much I agree with, but claim that the grounds for a Beauvoirian abolitionist position regarding punishment in general is found in her ethics.

27 "événement absolu" (Beauvoir 1947, 110).

28 "scandaleuse" (Beauvoir 1947, 121).

29 "presque annulé" (Beauvoir 1947, 121).

30 It is telling that Beauvoir phrases this principle in the negative-the ethics "will refuse to deny" ("ce sera une morale qui refusera de nier" [Beauvoir 1947, 24]) - rather than simply stating what the ethics proclaims. Indeed, it would be a mistake to argue that Beauvoir has an unambiguous relationship to ethical injunctions, as well as to violence and the condemnation of violence through judgment. However, in these clear textual moments ambiguity points to a definite ethical horizon-of freedom, of equality and peace-that itself informs the manner in which ambiguity is taken up and lived.

31 "[T]o will oneself moral and to will oneself free are one and the same decision" (Beauvoir 1948, 24).

32 The openness of the future makes it so that my freedom can affirm itself in time only once it seeks "to extend itself by means of the freedom of the others" (Beauvoir 1948, 60). This in turn necessitates that "the freedom of the other men must be respected...". Others provide meaning to the world in which my freedom materializes; the more committed I am to their freedom, the more I make sure that the world in which I act is a fertile ground for action (71). Finally, others validate my own free project. Yet they can do so only to the extent that I value them as free subjects, able to provide such validation (72).

33 La Caze demonstrates that in "Eil pour œil" Beauvoir portrays evil as something that can be done "negligently or thoughtlessly" (La Caze 2018, 28). This, I take it, is the attitude of the sub-man.

34 "mépris" (Beauvoir 1947, 57); "dégoût" (58).

35 She identifies the sub-man with "lynching. . . pogroms . . . the great bloody movements organized by the fanaticism of seriousness and passion" (Beauvoir 1948, 44).

36 For further support for this reading, see Arp 2001, 2-3.

37 There are such utopian moments in Beauvoir's philosophy of liberation. Consider, for example, her description of a postpatriarchal world in Le Deuxième sexe as a world where no one "would . . be tempted to contend for false privileges; and fraternity could then be born between them" (Beauvoir 2011, 763). In this respect I disagree with Murphy and, more recently, Stawarska, who think that in Beauvoir violence is a productive force (Murphy 2012; Stawarska 2020).

38 "il est peut-être permis de rêver à un avenir ou les hommes ne connaitront d'autre usage de leur liberté que ce libre déploiement d'elle-même..." (Beauvoir 1947, 114).

39 Describing the adventurer's existence, Beauvoir refers to this choice of being as close to an authentic moral attitude. "Ce choix est très proche, on le voit, d'une attitude authentiquement morale" (Beauvoir 1947, 75).

40 Beauvoir is probably referring to class privilege, although this holds equally true for her racial privilege, which she does not discuss. 
41 In southern Australia, restorative justice practices are currently permitted only after the person admits to having committed an offense to the police or the court (Daly and Stubbs, 2006, 24, note 7).

42 Beauvoir's conceptualization of ethical commitment as communal in principle, as involving an obligation to the freedom of others, renders her valuable for thinking about the well-being of our communities. In this context, one could expand the scope of the present investigation into penal abolition to police abolition, which has now, perhaps for the first time-after the BLM demonstrations of summer 2020-materialized as a genuine possibility.

\section{References}

Arendt, Hannah. 1977. Between past and future: Eight exercises in political thought. New York: Penguin Books.

Arp, Kristana. 2001. The bonds of freedom. Chicago: Open Court.

Beauvoir, Simone de. 1946. CEil pour œil. Les temps moderne 1 (5): 813-30.

Beauvoir, Simone de. 1947. Pour une morale de l'ambiguité. Paris: Gallimard.

Beauvoir, Simone de. 1948. The ethics of ambiguity. New York: Philosophical Library.

Beauvoir, Simone de. 1992. Force of circumstances: The autobiography of Simone de Beauvoir. Trans. Richard Howard. New York: Paragon House.

Beauvoir, Simone de. 2004. An eye for an eye. In Simone de Beauvoir: Philosophical writings, ed. Margaret A Simons, Marybeth Timmermann, and Mary Beth Mader. Urbana: University of Illinois Press.

Beauvoir, Simone de. 2011. The second sex. Trans. Constance Borde and Sheila Malovany-Chevallier, New York: Alfred A. Knopf.

Bergoffen, Debra B. 1997. The philosophy of Simone de Beauvoir: Gendered phenomenologies, erotic generosities. Albany: State University of New York Press.

Daly, Kathleen, and Julie Stubbs. 2006. Feminist engagements with restorative justice. Theoretical Criminology 10 (1): 9-28.

Davis, Angela Y. 2003. Are prisons obsolete? New York: Seven Stories Press.

Gines, Kathryn T. 2014. Comparative and competing frameworks of oppression in Simone de Beauvoir's The Second Sex. Graduate Faculty Philosophy Journal 35 (1-2): 251-73.

Kaplan, Alice. 2000. The collaborator: The trial and execution of Robert Brasillach. Chicago: University of Chicago Press.

Kruks, Sonia. 2012. Simone de Beauvoir and the politics of ambiguity. Oxford: Oxford University Press.

La Caze, Marguerite. 2018. Ethical restoration after communal violence: The grieving and the unrepentant. New York: Lexington Books.

Marso, Lori, J. 2012. Simone de Beauvoir and Hannah Arendt: Judgments in dark times. Political Theory 40 (2): 165-93.

Mathiesen, Thomas. 2015. The politics of abolition revisited. Oxford: Routledge.

Murphy, Ann. V. 2011. Violence is not an evil: Ambiguity and violence in Simone de Beauvoir's early philosophical writings. philoSOPHIA 1 (1): 29-44.

Murphy, Ann. 2012. Violence and the philosophical imaginary. Albany: State University of New York Press.

Stawarska, Beata. 2020. Struggle and violence: Entering the dialectic with Frantz Fanon and Simone de Beauvoir. In Violence and slavery in Hegel and Fanon, ed. U. Kistner and P. Van Haute. Johannesburg, South Africa: Wits University Press.

Taylor, Chloë. 2009. Foucault, feminism, and sex crimes. Hypatia 24 (4): 1-25.

Whalley, Elizabeth, and Colleen Hackett. 2017. Carceral feminisms: The abolitionist project and undoing dominant feminisms. Contemporary Justice Review 2 (4): 456-73.

Lior Levy is a senior lecturer in philosophy at the University of Haifa, specializing in twentieth-century European philosophy, in particular phenomenology, existentialism, and feminism. Her work on Simone de Beauvoir and Luce Irigaray has been published in Hypatia and Ibsen Studies, respectively. She is currently writing a book on Jean-Paul Sartre's philosophy of theater.

Cite this article: Levy L (2021). Aporias of Blame and Punishment in Simone de Beauvoir's "CEil pour Eil". Hypatia 36, 598-618. https://doi.org/10.1017/hyp.2021.46 